\title{
EFFECT OF CHICKEN MANURE ON YIELD AND YIELD CRITERIA OF ONION (ALLIUM CEPA L.) AS SECOND CROP
}

\author{
YOLDAS, F. $.^{*}-$ CEYLAN, ${ }^{1}-$ MORDOGAN, N. ${ }^{2}$ \\ ${ }^{1}$ Department of Organic Production, Ödemiş Vocational Training High School, Ege University \\ 35750 İzmir, Turkey \\ ${ }^{2}$ Department of Soil Science and Plant Nutrition, Faculty of Agriculture, Ege University \\ 35100 İzmir, Turkey \\ *Corresponding author \\ e-mail: funda.yoldas@ege.edu.tr; phone: +90-542-322-5385; fax: +90-232-544-4356
}

(Received $13^{\text {th }}$ May 2019; accepted $16^{\text {th }}$ Jul 2019)

\begin{abstract}
This study was conducted to determine the residue effects of chicken manure on the yield and yield components of eight onion varieties as second crop after lettuce in field condition. Varieties (14-16, Burgaz, Karbeyazı, Naz, NWG, Perwana, Seyhan, Şampiyon) and also four different doses of chicken manure at the rates of $0,20,40,60 \mathrm{tha}^{-1}$ with the recommended dose of NPK were used. A non-fertilized parcel was used as control. The experiment was laid out in split plot design and replicated three times. Yield and yield components were investigated. According to the results residual effect of chicken manures and onion varieties as second crop significantly affected the yield and bulb production in the field condition. The application of chicken manure significantly improved yield, bulb weight, bulb height, number of shoot tip, number of dried leaf compared to control. Highest yields $\left(46.31 \mathrm{t} \mathrm{ha}^{-1}\right)$ were obtained in the parcels where the chicken manure was applied at a rate of $60 \mathrm{t} \mathrm{ha}^{-1}$. The onion cultivar Burgaz was more responsive to the chicken manure compared to other onion cultivars. The best yield was shown by the Burgaz cultivar under $60 \mathrm{t} \mathrm{ha}^{-1}$ chicken manure treatment, thus this method is the most suitable for onion production.
\end{abstract}

Keywords: onion, varieties, organic manure, NPK, yield

\section{Introduction}

Onion (Allium cepa L.) is a vegetable that is widely consumed due to its flavoring and health-promoting properties. Onions have many possible health benefits including reducing the risk of obesity, heart disease, and cancer. Onion bulb is a rich source of minerals like phosphorus, calcium, magnesium, iron, manganese and carbohydrates. It also contains protein, Vitamin C, Vitamin B6, and antioxidants (Ware, 2017).

According to the statistics, Turkey's bulb onion production is 2131513 ton in 576918 ha area (Anonymous, 2017).

Healthy life and environmental consciousness are important today. In this case it caused to increase on natural feeding. Using of chemical matter was decreased and natural productions get importance. But soil fertility is important in this case. Organic matter improves soil's physical, chemical, biological properties and is also effect the availability of nutrient. But high level organic material in soils especially in dry conditions may be caused unable effects and also it can be create organo-mineral complex and it reduced the availability of some mineral (Sezen, 1995). Animal fertilizers are major source of organic matter for soil.

Boyhan and Hill (2008) found that fertilizer requirements were higher with organic fertilizer sources compared with conventional fertilizers presumably because nutrients were less available in organic compounds due to slow mineralization rates. 
Work has been done to predict the availability of plant nutrients from organic sources over time. Whitmore (2007), for example, found that $40 \%$ of the total $\mathrm{N}$ from composted chicken manure was available in the first year, with the remainder available in subsequent years at a rate of 6 to $12 \%$ per year.

Many researchers reported that soil application of chicken manure increased yield and yield criteria of onion (Shaheen et al., 2007; Dina et al., 2010; El-Shatanofy and Manar, 2011; Yoldas et al., 2011; Ali et al., 2018).

Comparisons of conventional and organic farms matched by soil type indicated that organic practices improved soil fertility (Liebig and Doran, 1999). This included a 22\% increase in organic matter, $20 \%$ more total $\mathrm{N}$, lower bulk density and higher water holding capacity.

Many authors reported that the onion yield and bulb production was significantly affected by onion cultivars (Soleymani and Shahrajabian, 2012; Ali et al., 2018).

The objective of this study was to evaluate the residue effect of chicken manure on yield and yield criteria of onion as second crop in field condition.

\section{Materials and methods}

The study was carried out in experimental area of the Ödemiş Vocational School, at the Ege University, in İzmir (38 $\left.16^{\prime} \mathrm{N}, 2^{\circ} 59^{\prime} \mathrm{E}\right)$ during the 2017 year. The experimental designs were split plot with three replications. Before sowing of lettuce, the chicken manure were applied to soil at the rates of $0-20-40-60 \mathrm{t} \mathrm{ha}^{-1}$ and also recommended dose of NPK (150:100:150 kg ha-1). Five different treatments with control and three replications were conducted in 15 plots. Lolla Rossa lettuce variety was sown and harvested at the end of vegetation. After harvesting the lettuce plant, onion varieties was sown in order to determine the residual effect of chicken manure and chemical fertilizer in field conditions. No nutrient addition was made for onion. In this study, during the growth period, weeds were removed by hand hoeing and irrigation was done on a regular basis.

Eight onion varieties called 14-16, Burgaz, Karbeyaz1, Naz, NWG, Pewana, Seyhan, Şampiyon were used. Allium cepa L. was planted in each plot with $30 \mathrm{~cm}$ between rows and $15 \mathrm{~cm}$ above the rows. Total plot length is $11.5 \mathrm{~m}$ and plot width is $6.2 \mathrm{~m}$.

The composition of chicken manure that residual effect investigated was analyzed according to Kacar (1995) and is presented in Table 1.

Table 1. Some properties of chicken manure

\begin{tabular}{c|c}
\hline $\mathrm{pH}$ & 8.55 \\
Total salt $(\mathrm{ms} / \mathrm{cm})$ & 2.47 \\
Ash 550 ${ }^{\circ} \mathrm{C}(\%)$ & 79 \\
Organic matter $(\%)$ & 19.8 \\
Organic carbon (\%) & 11.51 \\
Total N (\%) & 0.95 \\
$\mathrm{C} / \mathrm{N}$ & 12.1 \\
$\mathrm{P}(\%)$ & 0.70 \\
$\mathrm{~K}(\%)$ & 1.02 \\
$\mathrm{Ca}(\%)$ & 1.37 \\
$\mathrm{Mg}(\mathrm{ppm})$ & 3729 \\
$\mathrm{Na}(\mathrm{ppm})$ & 1248 \\
\hline
\end{tabular}


Soil samples $(0-30 \mathrm{~cm})$ were collected from the individual experimental plots $(15$ samples) at the beginning of onion vegetation. The soil sample was air dried, ground, and passed through $2 \mathrm{~mm}$ sieve for the determination of chemical parameters. $\mathrm{pH}$ (Jackson, 1967), total soluble salt (Anonymous, 1951), $\mathrm{CaCO}_{3}$ (Kacar, 1995), organic matter content (Reuterberg and Kremkurs, 1951) were determined in the soil. Total N was also analyzed according to Bremner (1965), the available $\mathrm{K}^{+}$, was determined after extracting with $1 \mathrm{~N} \mathrm{NH}_{4} \mathrm{OAc}$ by flame photometer (Atalay et al., 1986) and available $\mathrm{P}$ was measured by colorimeter (Olsen et al., 1954).

At the end of the vegetation, the plants were harvested. Average bulb head weight, bulb height, bulb width and flesh thickness, number of storage leaf, number of shoot tip, and number of dried leaf were determined as growth and yield parameters.

Ten randomly selected plants were harvested from each plot (avoiding side effect) to record the data on data set for all characters. Bulb length and diameter refers to the height of the bulb and the average width at the widest point in the middle portion of the mature bulb measured using vernier caliper. Average bulb weight computed by weighing ten bulbs together and calculating the average.

Total bulb yield was computed based on the weight of matured bulbs yield per plot and converted in to hectare base and expressed in tones. Marketable bulb yield was determined after discarding bulbs smaller than $3 \mathrm{~cm}$ in diameter, splitted, thick necked, rotten and discolored. Split bulbs percentage was determined by counting the number of split bulbs per plot and expressed in percentage in reference to total number of normal bulbs per plot.

The collected data on various parameters were statistically analyzed. Analysis of variance was computed and LSD was used to compare means. Trial statistical evaluation result of data was done using software package TARIST (Açikgöz et al., 1993).

\section{Results and discussion}

\section{Soil properties}

The physical and chemical properties of soils before onion sowing are presented in Tables 2 and 3. $\mathrm{pH}$, organic matter, lime values in the soil did not show any statistical difference between applications at the beginning of vegetation. On the contrary, the salt, $\mathrm{N}, \mathrm{P}, \mathrm{Na}, \mathrm{Fe}$ content of the soil was significantly affected by the applications. The highest values were analyzed in the parcels which the chicken manure was applied as $60 \mathrm{tha}^{-1}$.

Table 2. Some chemical properties of field trial soils at the beginning of onion vegetation

\begin{tabular}{c|c|c|c|c}
\hline Treatment & $\mathbf{p H}$ & Salt $(\boldsymbol{\mu S} / \mathbf{c m})$ & O.M. $(\boldsymbol{\%})$ & CaCO3 $_{(\%)}$ \\
\hline 0 & 7.06 & $183 \mathrm{ab}$ & 0.66 & 0.63 \\
NPK & 7.00 & $160 \mathrm{~b}$ & 0.89 & 0.84 \\
$20 \mathrm{t} \mathrm{ha}^{-1}$ & 7.08 & $168 \mathrm{ab}$ & 0.83 & 0.69 \\
$40 \mathrm{t} \mathrm{ha}^{-1}$ & 6.98 & $221 \mathrm{a}$ & 0.72 & 0.72 \\
$60 \mathrm{t} \mathrm{ha}^{-1}$ & 7.02 & $185 \mathrm{ab}$ & 0.79 & 0.66 \\
LSD & n.s. & $57.25^{*}$ & n.s. & n.s. \\
\hline
\end{tabular}

$* * \mathrm{p}<0.01 ;$ n.s.: not significant 
Table 3. Macro-micro nutrient contents of field trial soils at the beginning of vegetation

\begin{tabular}{|c|c|c|c|c|c|c|}
\hline Treatment & $\begin{array}{c}\text { Total N } \\
(\%)\end{array}$ & $\begin{array}{c}\mathbf{P} \\
\left(\mathrm{mg} \mathrm{kg}^{-1}\right)\end{array}$ & $\begin{array}{c}\mathbf{K} \\
\left(\mathrm{mg} \mathrm{kg}^{-1}\right)\end{array}$ & $\begin{array}{c}\mathrm{Ca} \\
\left(\mathrm{mg} \mathrm{kg}^{-1}\right) \\
\end{array}$ & $\begin{array}{c}\mathrm{Mg} \\
\left(\mathrm{mg} \mathrm{kg}^{-1}\right) \\
\end{array}$ & $\begin{array}{c}\mathrm{Na} \\
\left(\mathrm{mg} \mathrm{kg}^{-1}\right)\end{array}$ \\
\hline 0 & $0.056 \mathrm{c}$ & $24.16 \mathrm{~b}$ & 100.6 & 1056 & 224 & $16.26 \mathrm{~d}$ \\
\hline NPK & $0.090 \mathrm{~b}$ & $34.56 \mathrm{a}$ & 98.0 & 1023 & 215 & $27.96 \mathrm{bc}$ \\
\hline $20 \mathrm{tha}^{-1}$ & $0.076 \mathrm{~b}$ & $27.59 \mathrm{~b}$ & 97.4 & 986 & 210 & $23.90 \mathrm{~cd}$ \\
\hline $40 \mathrm{tha}^{-1}$ & $0.081 \mathrm{~b}$ & $24.72 \mathrm{~b}$ & 80.9 & 891 & 220 & $32.13 \mathrm{~b}$ \\
\hline $60 \mathrm{tha}^{-1}$ & $0.110 \mathrm{a}$ & $35.50 \mathrm{a}$ & 106.7 & 1089 & 218 & $42.90 \mathrm{a}$ \\
\hline LSD & $0.018 * *$ & $5.92 * *$ & n.s. & n.s. & n.s. & $8.15^{* *}$ \\
\hline \multicolumn{2}{|c|}{ Treatment } & $\begin{array}{c}\mathrm{Fe} \\
\left(\mathrm{mg} \mathrm{kg}^{-1}\right)\end{array}$ & $\begin{array}{c}\mathrm{Zn} \\
\left(\mathrm{mg} \mathrm{kg}^{-1}\right)\end{array}$ & \multicolumn{2}{|c|}{$\begin{array}{c}\mathrm{Mn} \\
\left(\mathrm{mg} \mathrm{kg}^{-1}\right)\end{array}$} & $\begin{array}{c}\mathrm{Cu} \\
\left(\mathrm{mg} \mathrm{kg}^{-1}\right)\end{array}$ \\
\hline \multicolumn{2}{|l|}{0} & $3.38 \mathrm{~b}$ & 1.06 & \multicolumn{2}{|c|}{3.68} & 0.64 \\
\hline \multicolumn{2}{|l|}{ NPK } & $3.75 \mathrm{a}$ & 1.19 & \multicolumn{2}{|c|}{4.03} & 0.63 \\
\hline \multicolumn{2}{|l|}{$20 \mathrm{tha}^{-1}$} & $3.49 \mathrm{ab}$ & 1.16 & \multicolumn{2}{|c|}{4.13} & 0.67 \\
\hline \multicolumn{2}{|l|}{$40 \mathrm{t} \mathrm{ha}^{-1}$} & $3.49 \mathrm{ab}$ & 3.03 & \multicolumn{2}{|c|}{4.04} & 0.65 \\
\hline \multicolumn{2}{|l|}{$60 \mathrm{t} \mathrm{ha}^{-1}$} & $3.75 \mathrm{a}$ & 1.09 & \multicolumn{2}{|c|}{4.15} & 0.63 \\
\hline \multicolumn{2}{|l|}{ LSD } & $0.368 *$ & n.s. & \multicolumn{2}{|c|}{ n.s. } & n.s. \\
\hline
\end{tabular}

$* * \mathrm{p}<0.01 ;$ n.s.: not significant

Before onion sowing, field soil properties are neutral (6.6-7.3), humus $(<1 \%)$ and lime (0-2.5) poor. When the productivity status of the soil is investigated, $\mathrm{N}$ is moderate $(0.05-0.1 \%)$; $\mathrm{K}(<150 \mathrm{ppm}), \mathrm{Ca}(715-1430 \mathrm{ppm})$ poor; rich in $\mathrm{P}(3.26 \mathrm{ppm})$; $\mathrm{Mg}$ (large $114 \mathrm{ppm}$ ) is good; Fe (large $4.5 \mathrm{ppm}$ ); Zn (large $1 \mathrm{ppm}$ ), Mn (large $1 \mathrm{ppm}$ ), $\mathrm{Cu}$ (large $0.2 \mathrm{ppm}$ ) is determined to be sufficient according to Güneş et al. (2000).

\section{Onion yield and yield characteristics}

Residue effect of chicken manure on yield and some quality criteria of onion as second crop after the lettuce production are given in Table 4.

In the field condition, the results showed significant differences in yield amongst treatments $(\mathrm{p}<0.01)$ (Table 4). Highest yields $\left(46.31 \mathrm{t} \mathrm{ha}^{-1}\right)$ were obtained in the parcels which the chicken manure was applied as $60 \mathrm{t} \mathrm{ha}^{-1}$. This application increased yield by $44 \%$ compared to the control plots. But there was no statistically significant difference in yield between mineral fertilizer and $60 \mathrm{t} \mathrm{ha}^{-1}$ of chicken manure application. Similarly Rumpel (1998), Sharma et al. (2003), Yoldas et al. (2011), Indira and Singh (2014), Zewde et al. (2018) found that animal manure applications increased onion yield. Organic manures activate many species of living organisms which release phytohormones and may stimulate the plant growth and absorption of nutrients (Arisha et al., 2003). Organic manures improved the water holding capacity of soil and provide nutrients for a long duration due to less leaching of nutrients and increase efficiency (Carol et al., 1999). Mahala et al. (2018) reported that the increased yield and yield parameters with poultry manure might be because of rapid availability and utilization of nitrogen for various internal plant processes for carbohydrates production. Later on these carbohydrates may undergo hydrolysis and get converted into reproductive sugars which ultimately helped in increasing yield. 
Table 4. Residue effect of chicken manure on yield and some quality criteria of onion as second crop in the field condition

\begin{tabular}{c|c|c|c|c|c|c|c}
\hline Treatment & $\begin{array}{c}\text { Yield } \\
\left.\mathbf{( t ~ h a - 1}^{-1}\right)\end{array}$ & $\begin{array}{c}\text { Bulb } \\
\text { weight } \\
\left(\mathbf{g ~ n o}^{-1}\right)\end{array}$ & $\begin{array}{c}\text { Bulb } \\
\text { width } \\
(\mathbf{c m})\end{array}$ & $\begin{array}{c}\text { Bulb } \\
\text { height } \\
(\mathbf{c m})\end{array}$ & $\begin{array}{c}\text { Number of } \\
\text { stored leaf } \\
(\mathbf{n o})\end{array}$ & $\begin{array}{c}\text { Number of } \\
\text { shoot tip } \\
(\mathbf{n o})\end{array}$ & $\begin{array}{c}\text { Number of } \\
\text { dried leaf } \\
(\text { no })\end{array}$ \\
\hline 0 & $32.13 \mathrm{bc}$ & $96.4 \mathrm{bc}$ & 4.4 & $6.7 \mathrm{ab}$ & 6.1 & 1.3. & 2.6 \\
$\mathrm{NPK}$ & $44.06 \mathrm{a}$ & $132.0 \mathrm{a}$ & 4.9 & $7.2 \mathrm{a}$ & 6.5 & 1.2 & 3.1 \\
$20 \mathrm{t} \mathrm{ha}^{-1}$ & $34.63 \mathrm{~b}$ & $103.9 \mathrm{~b}$ & 4.5 & $6.9 \mathrm{ab}$ & 6.5 & 1.4 & 2.9 \\
$40 \mathrm{t} \mathrm{ha}^{-1}$ & $30.39 \mathrm{c}$ & $90.8 \mathrm{c}$ & 4.3 & $6.5 \mathrm{~b}$ & 6.4 & 1.4 & 2.9 \\
$60 \mathrm{t} \mathrm{ha}^{-1}$ & $46.31 \mathrm{a}$ & $138.9 \mathrm{a}$ & 4.9 & $6.8 \mathrm{ab}$ & 6.5 & 1.5 & 3.2 \\
$\mathrm{LSD}$ & $4.129 * *$ & $12.2 * *$ & n.s. & $0.5^{*}$ & n.s. & $0.18^{*}$ & $0.6^{* *}$ \\
\hline
\end{tabular}

$* * \mathrm{p}<0.01 ; * \mathrm{p}<0.05 ;$ n.s.: not significant

\section{Yield}

Similar to the results Velmurugan and Swarnam (2017), explained that rice grain yield were significantly affected by the residual effect of manures and Inorganic fertilizer to okra, different our results, Abdelrezzag (2002) reported that chicken manure tend to reduce onion yield for all levels in comperation with fertilizer and control.

In the study, the highest yield was observed Burgaz variety $(\mathrm{p}<0.01)$ (Table 5). Highest yield after Burgaz obtained with Şampiyon variety. The differences in yield among varieties can be caused by differences in genetic characteristics of varieties (Khan et al., 2011).

The interaction between onion cultivars and treatment was found statistically significant on yield. Maximum yield was obtained in Burgaz variety with the $60 \mathrm{t} \mathrm{ha}^{-1}$ of chicken manure application as $79.87 \mathrm{t} \mathrm{ha}^{-1}$. Hasan et al. (2018) reported similar results in their studies.

\section{Bulb weight}

Treatments, variety and the interaction between onion cultivars and treatment affected bulb weight of onion significantly ( $p<0.01)$. Highest values $(138 \mathrm{~g})$ were obtained in the parcels which the chicken manure was applied as $60 \mathrm{t} \mathrm{ha}^{-1}$ in the field (Table 4). This application increased weight of onion by $44 \%$ compared to the control plots. But there was no statistically significant difference in bulb weight between mineral fertilizer and $60 \mathrm{t} \mathrm{ha}^{-1}$ of chicken manure application. Similarly, Yohannes et al. (2013) reported that farmyard manure and nitrogen fertilizer increased bulb weight. Organic fertilizers provide nutrients to the plants by decomposing and increase growth and yield. Manures improved the soil structure, fertile and availability of nutrient to the plant. Better nutrition of the plant; increase the cell division of plant tissues and the rate of photosynthesis. This is reflected in product growth and the bulb weight (Ewais et al., 2010).

Bulb weights of Burgaz variety (195.2 g) were higher than the others onion variety significantly (Table 5).

The interaction between onion cultivars and treatment for bulb weight was found statistically significant The highest bulb weights was obtained in Burgaz variety with mineral fertilizer as $268.7 \mathrm{~g}$ in the field condition. 
Table 5. Effect of variety on yield and same quality criteria of onion as second crop depending on residue effect of chicken manure in the field condition

\begin{tabular}{c|c|c|c|c|c|c|c}
\hline Variety & $\begin{array}{c}\text { Yield } \\
\left(\mathbf{t ~ h a} \mathbf{- 1}^{-1}\right)\end{array}$ & $\begin{array}{c}\text { Bulb } \\
\text { weight } \\
\left(\mathbf{g} \mathbf{~ n o}^{-\mathbf{1}}\right)\end{array}$ & $\begin{array}{c}\text { Bulb width } \\
(\mathbf{c m})\end{array}$ & $\begin{array}{c}\text { Bulb height } \\
(\mathbf{c m})\end{array}$ & $\begin{array}{c}\text { Number of } \\
\text { storage leaf } \\
(\mathbf{n o})\end{array}$ & $\begin{array}{c}\text { Number of } \\
\text { shoot tip } \\
(\mathbf{n o})\end{array}$ & $\begin{array}{c}\text { Number of } \\
\text { dried leaf } \\
(\mathbf{n o})\end{array}$ \\
\hline $14-16$ & $32.42 \mathrm{~d}$ & $97.3 \mathrm{~d}$ & $4.4 \mathrm{cde}$ & $6.8 \mathrm{bc}$ & $5.8 \mathrm{c}$ & $1.7 \mathrm{a}$ & $2.8 \mathrm{~cd}$ \\
Burgaz & $65.06 \mathrm{a}$ & $195.2 \mathrm{a}$ & $5.8 \mathrm{a}$ & $7.9 \mathrm{a}$ & $7.4 \mathrm{a}$ & $1.3 \mathrm{bcd}$ & $4.7 \mathrm{a}$ \\
Kar Beyaz1 & $39.09 \mathrm{c}$ & $117.3 \mathrm{c}$ & $4.7 \mathrm{bc}$ & $7.5 \mathrm{ab}$ & $6.9 \mathrm{a}$ & $1.1 \mathrm{~d}$ & $3.4 \mathrm{~b}$ \\
Naz & $25.26 \mathrm{f}$ & $75.3 \mathrm{f}$ & $3.9 \mathrm{e}$ & $5.9 \mathrm{~d}$ & $6.8 \mathrm{ab}$ & $1.1 \mathrm{~cd}$ & $2.3 \mathrm{e}$ \\
NWG & $28.29 \mathrm{def}$ & $84.9 \mathrm{def}$ & $4.1 \mathrm{de}$ & $6.8 \mathrm{bc}$ & $5.5 \mathrm{c}$ & $1.5 \mathrm{ab}$ & $3.1 \mathrm{bc}$ \\
Perwana & $32.08 \mathrm{de}$ & $96.3 \mathrm{de}$ & $4.6 \mathrm{bcd}$ & $6.1 \mathrm{~cd}$ & $6.9 \mathrm{ab}$ & $1.7 \mathrm{a}$ & $2.6 \mathrm{~d}$ \\
Seyhan & $28.13 \mathrm{ef}$ & $84.1 \mathrm{ef}$ & $4.3 \mathrm{cde}$ & $6.3 \mathrm{~cd}$ & $5.7 \mathrm{c}$ & $1.4 \mathrm{abc}$ & $1.8 \mathrm{f}$ \\
Şampiyon & $49.66 \mathrm{~b}$ & $148.9 \mathrm{~b}$ & $5.1 \mathrm{~b}$ & $7.4 \mathrm{ab}$ & $6.2 \mathrm{bc}$ & $1.1 \mathrm{~d}$ & $2.9 \mathrm{~cd}$ \\
LSD & $4.228 * *$ & $12.7 * *$ & $0.56 * *$ & $0.8 * *$ & $0.7 * *$ & $0.3 * *$ & $0.5 * *$ \\
\hline
\end{tabular}

$* * \mathrm{p}<0.01 ; * \mathrm{p}<0.05 ;$ n.s.: not significant

\section{Bulb width}

The residual effect of chicken manure and mineral NPK applications on onion bulb width not found significant (Table 4). Similarly, Yohannes et al. (2013) and Mekonnen et al. (2017) reported that farmyard manure did not affect bulb length of onion in their work.

The highest bulb width $(5.8 \mathrm{~cm})$ was observed Burgaz variety $(\mathrm{p}<0.01)$ followed by the bulb width $(5.1 \mathrm{~cm})$ in Şampiyon variety (Table 5). The interaction between onion cultivars and treatment for bulb width was statistically important. Maximum bulb was obtained in Burgaz variety with the mineral NPK application as $6.60 \mathrm{~cm}$.

The differences in the responses to the applications of onion varieties may be genetic variation and also depending on the adoptability of variety in specific environment (Shah et al., 2012; Ali et al., 2018).

\section{Bulb height}

Onion bulb height was significantly $(\mathrm{p}<0.01)$ affected by the residual effect of chicken manure and mineral NPK applications (Table 4). The highest value $(7.2 \mathrm{~cm})$ was determined in mineral NPK application and followed bulb height $(6.9 \mathrm{~cm})$ by the application of chicken manure as $20 \mathrm{t} \mathrm{ha}^{-1}$. Similarly, Yohannes et al. (2013) reported that application of FYM at a rate of 45 ton ha $^{-1}$ gave the highest mean bulb diameter (5.99 $\mathrm{cm}$ ). Consistent with the results Metwally and Bary (1999) suggested that the poultry manure improve the bulb growth by enhancing the soil properties and overcome the leaching of nutrients from the root zone. As different Mekonnen et al. (2017) reported that organic manure did not significantly influence bulb length.

In the study, bulb height of Burgaz variety $(7.9 \mathrm{~cm})$ was reported higher than other varieties $(\mathrm{p}<0.01)($ Table 5). The interaction between onion cultivars and treatment for bulb height was found non-significant.

\section{Number of storage leaf}

According to statistical analyzes, number of storage leaf was not affected from the treatments. But these characteristics have changed significantly in relation to the varieties 
(Tables 4 and 5). Highest value was obtained in Burgaz variety $(7.4 \mathrm{~cm})$ followed Şampiyon variety (6.9) (Table 5). However, there was no statistically significant difference between Burgaz and Şampiyon variety. The interaction between onion cultivars and treatment had a significant effect on the number of storage leaf $(p<0.01)$. The number of storage leaf was higher in the application of mineral fertilizer and Burgaz variety.

\section{Number of shoot tip}

The results presented in (Tables 4 and 5) showed that treatment and onion variety had significantly affected number of shoot tip of onion, where the interaction had also significantly affected. The highest number of shoot tip (1.5) was observed with the application of chicken manure at the rate of $60 \mathrm{t} \mathrm{ha}^{-1}$. While the lowest numbers of shoot tip (1.2) was observed in mineral NPK aplication. Among the onion variety highest number of shoot tip was recorded in variety 14-16 and Perwana.

Maximum number of shoot tip was obtained in 14-16 varieties with the $60 \mathrm{t} \mathrm{ha}^{-1}$ of chicken manure application as $20 \mathrm{t} \mathrm{ha}^{-1}$.

\section{Number of dried leaf}

Treatments, variety and the interaction between onion cultivars and treatment affected number of dried leaf of onion significantly ( $\mathrm{p}<0.01)$ (Tables 4 and 5). Highest value (3.2) was obtained in the parcels which the chicken manure was applied as $60 \mathrm{t} \mathrm{ha}^{-1}$ in the field. Number of dried leaf of Burgaz variety (4.7) were higher than the others onion variety significantly (Table 5). The highest number of dried leaf was obtained in Burgaz variety with mineral fertilizer as 6.2.

\section{Conclusion}

As a result it was found that residual effect of chicken manures and onion varieties as second crop significantly affected the yield and bulb production in the field condition. Residual of chicken manure increased yield, bulb weight, bulb height, number of dry shell, number of shoots of onion varieties. The highest results were obtained especially with $60 \mathrm{t} \mathrm{ha}^{-1}$ of chicken manure application in the field condition. The onion varieties Burgaz gave more response to the organic manure as compare with other onion varieties in yield, bulb weight, bulb height, bulb width, number of storage leaf and number of dried leaf.

The interaction of chicken manure and onion cultivar also affected the yield of onion. The best yield was shown by Burgaz cultivar under $60 \mathrm{t} \mathrm{ha}^{-1}$ chicken manure treatment, thus this method is the most suitable for onion production.

In today's world, where healthy life and environmental consciousness is gaining importance, it should be aimed to increase the conscious use of natural organic fertilizers.

Acknowledgements. This research is a work supported by Scientific Research Project Commission of Ege University; Contact no: 2017/OMYO/001. 


\section{REFERENCES}

[1] Abdelrazzag, A. (2002): Effect of chicken manure, sheep manure and inorganic fertilizer on yield and nutrients uptake by onion. - Pakistan J. Biol. Sci. 5(3): 266-268.

[2] Açikgöz, N., Akka, M. E., Maghaddam, A., Özcan, K. (1993): Database dependent. Congress of International Practice of Computer.

[3] Ali, M., Khan, N., Khan, A., Ullah, R., Naeem, A., Khan, M. W., Khan, K., Farooq, S., Rauf, K. (2018): Organic manures effect on the bulb production of onion cultivars under semiarid condition. - Pure Appl. Biol. 7(3): 1161-1170.

[4] Anonymous (1951): U. S. Soil Survey Staff, Soil Survey Manual. U. S. Dept. Agr. Handbook 18. - U. S. Govt. Printing Office, Washington DC, USA.

[5] Anonymous (2017): Plant Production Statistics. - www.tuik.gov.tr.

[6] Arisha, H. M. E., Gad, A. A., Younes, S. E. (2003): Response of some pepper cultivars to organic and mineral nitrogen fertilizer under sandy soil conditions. - Zagazig J. Agr. Res. 30: $1875-1899$.

[7] Atalay, I. Z., Kılınç, R., Anaç, D., Yokaş, İ. (1986): Gediz havzası rendzina topraklarının potasyum durumu ve bu topraklarda alınabilir potasyum miktarlarının tayininde kullanılacak yöntemler. - Bilgehan Matbaası, İzmir.

[8] Boyhan, G. E., Hill, C. R. (2008): Organic fertility sources for the production of shortday organic onion transplants. - Hort. Technology 18: 227-231.

[9] Bremner, J. M. (1965): Total Nitrogen. - In: Black, C. A., Evans, D. D., White, J. L., Ensminger, L. E., Clark, F. E., Dinauer, R. C. (eds.) Methods of Soil Analysis. Part 2: Chemical and Microbiological properties. Am. Soc. of Agron., Madison, WI, pp. 11491237.

[10] Carol, M., Tanya, C., Tamera, F. (1999): A Manure Resource Guide for Farmers and Gardeners in Western Washington. - King Conservation, Renton, WA.

[11] Dina, M. S., Shafeek, M. R., Abdallah, M. M. F. (2010): Effect of different nitrogen sources and soil solarization on green onion productivity for exportation. - Annals of Agric. Sci., Cairo Univ. 55(1): 97-106.

[12] El-Shatanofy, Manar, M. E. (2011): Influence of organic manure and inorganic fertilizers on growth, yield and chemical contents of onion (Allium cepa, L.). - M.Sc. Thesis, Fac. of Agric., Alex. Univ., Alexandria.

[13] Ewais, M. A., Mahmoud, A. A., Khalil, A. A. (2010): Effect of nitrogen fertigation in comparison with soil application on onion production in sandy soils. - Alex J Agric Res 55(3): 75-83.

[14] Güneş, A., Alpaslan İnal, M. (2000): Bitki besleme ve gübreleme. - Ankara Üniversitesi Ziraat Fak. 1514: 199.

[15] Hassan, S. A. E., Elmehrat, H. G., Ragab, A. A., Abdel Megiud, M. A., Dahab, A. (2018): Growth, yield, bulb quality and storability of some onion cultivars response to compost, vermicompost and plant growth promoting Rhizobacteria. - Middle East J. Agric. Res. 7(2): 292-306.

[16] Indira, S., Singh, S. J. (2014): Effect of vermicompost and biofertilizer on yield and quality of rabi onion (Allium cepa L) CV. - Puna Red. Agric. Sci. Digest. 34(2): 144146.

[17] Jackson, M. L. (1967): Soil Chemical Analysis. - Prentice Hall, New Delhi.

[18] Kacar, B. (1995): Toprak analizleri: Bitki ve toprağın kimyasal analizleri III. - Ankara Üni., Zir. Fak., Eğitim Araş. ve Geliştirme Vakfi Yayınları, pp.81-86.

[19] Khan, I. M., Hassan, G., Khan, I., Marwat, K. B. (2011): Testing of herbicides at various doses on the growth stages of wild onion grown in pots. - Sarhad J Agric 27(1): 85-91.

[20] Liebig, M. A., Doran, J. W. (1999): Impact of organic production practices on soil quality indicators. - J. Environ. Qual. 28: 1601-1609. 
[21] Mahala, P., Chaudhary, M. R., Garhwal, O. P. (2018): Yield and quality of rabi onion (Allium cepa L.) influenced by integrated nutrient management. - Int. J. Curr. Microbiol. App. Sci. 7(5): 3313-3321.

[22] Mekonnen, D. A., Mihretu, F. G., Woldetsadi, K. (2017): Farmyard manure and intra-row spacing on yield and yield components of adama red onion (Allium cepa L.) cultivar under irrigation in Gewane district, Afar Region, Ethiopia. - J. Hortic. For. 9(5): 40-48.

[23] Metwally, S. M., Abdel-Bary, E. A. (1999): Assessment of application of amendments to sandy soils using a computer model. - Zagazig J Agric Res 2: 947-962.

[24] Olsen, S. R., Cole, C. V., Watanbe, F. S., Dean, L. A. (1954): Estimation of available phosphorus in soils by extraction with sodium bicarbonate. - USDA Cir. No. 939.

[25] Reuterberg, E., Kremkus, F. (1951): Bestimmung von Gesamthumus und alkalischen Humusstoffen im Boden, z. Pflanzenernaehr. Düng. und Bodenkd. - Verlag Chemie $\mathrm{GmbH}$, Weinheim.

[26] Rumpel, J. (1998): Effect of long-term organic, mineral, and combined organic-mineral fertilization on yield of onions (Allium cepa L.) grown from seeds. - Biuletyn Warzywniczy 48: 5-15.

[27] Sezen, Y. (1995): Soil Chemistry. Edition of Ataturk University No: 790. - Atatürk Univ. Faculty of Agriculture, Erzurum.

[28] Shah, ST., Sajid, M., Alam, R., Rab, A., Mateen, A., Jan, I., Ali, A., Wahid, F. (2012): Comparative study of onion cultivars at Mardan, Khyber Pakhtunkhwa - Pakistan. Sarhad J Agric 28(3): 399-402.

[29] Shaheen, A., Fatma, M., Rizk, A., Singer, S. M. (2007): Growing onion plants without chemical fertilization. - Res. J. Agr. Biol. Sci. 3(2): 95-104.

[30] Sharma, R. P., Datt, N., Sharma, P. K. (2003): Combined application of nitrogen, phosphorus, potassium and farmyard manure in onion under high hills, dry temperate conditions of North-Western Himalayas. - Indian J. Agr. Sci. 73: 4: 225-227.

[31] Soleymani, A., Shahrajabian, M. H. (2012): Effects of different levels of nitrogen on yield and nitrate content of four spring onion genotypes. - Inter. J. of Agric. and Crop Sci. 4(4): 179-182.

[32] Velmurugan, A., Swarnam, P. (2017): Nutrient uptake and residual effect of organic treatments applied to vegetable-rice system in an acid soil. - Journal of Plant Nutrition 40(12): 1755-1772.

[33] Ware, M. (2017): https://www.medicalnewstoday.com/articles/276714.php. - Accessed on: 15.2.2019.

[34] Whitmore, A. P. (2007): Determination of the mineralization of nitrogen from composted chicken manure as affected by temperature. - Nutr. Cycl. Agroecosyst. 77: 225-232.

[35] Yohannes, K. W., Belew, D., Debela, A. (2013): Effect of farmyard manure and nitrogen fertilizer rates on growth, yield and yield components of onion (Allium cepa L.) at Jimma, Southwest Ethiopia. - Asian Journal of Plant Sciences 12 (6-8): 228-234.

[36] Yoldas, F., Ceylan, S., Mordogan, N, Esetlili, B. C. (2011): Effect of organic and inorganic fertilizers on yield and mineral content of onion (Allium cepa L.). - African J. of Biotech. 10(55): 1148811492.

[37] Zewde, A., Mulatu, A., Astatkie, T. (2018): Inorganic and organic liquid fertilizer effects on growth and yield of onion. - International Journal of Vegetable Science 24(6): 567573. 